\title{
Perceived Organizational Support: A Case of Special Education Teacher
}

\author{
Fadhilah Ramadhani, Indrianawati, \& NurAiny Fardana \\ Master of Professional Psychology Universitas Airlangga, \\ Faculty of Economics and Business Universitas Airlangga \\ e-mail: fadhilahramadhani1992@gmail.com, \\ indrianawati-u@feb.unair.ac.id, \\ nurainy.fardana@psikologi.unair.ac.id
}

\begin{abstract}
This study aims to examine perceived organizational support within special education teacher in Surabaya. Special education needs a lot more attention because some inclusive system in public schools are not well developed which affecting the teachers' well being. This study starts with a literature review building the knowledge basis for the topic. The primary data was gathered through several interviews with shadow teachers to look into the difficulty which resulted in lack of perceived organizational support among special education teachers. The perceived organizational support in teachers was examined through the three beneficial factors for POS, namely: fairness, supervisor support, and organizational rewards and job conditions. Result shows that the organization still need to improve the three beneficial factors for POS so that the teachers can feel more supported by the organization.
\end{abstract}

Keywords: perceived organizational support, special education teacher

\section{INTRODUCTION}

Indonesia is one of developing countries in South East Asia which starting to build educational system for children with disability. There are about 1,6 million children with special needs in Indonesia, but only $18 \%$ children that have been treated based on statistical data in Ministry Education and Culture in Indonesia.

Special needs education quality is influenced by other factors, such as curriculum, the educator quality, infrastructures, fund, management, environment, and the learning process (Zakia, 2015). Due to this condition, not only because the lack of appropriate educational services (Efendi, 2018) but also the teachers who are being neglected in terms of well-being, skill development, unspecified job description, and carrier sustainability (Zakia, 2015), special education teachers need more attention and consideration in the inclusive school, especially public school that has special needs students.
Sugianto (2012) as head master in SLB ACD Mojokerto, said that the amount of students in there are 64 with only 11 education staff, include 1 as head master and 1 as administration staff. In other school (Adi, 2008 in Firmansyah $\&$ Widuri, 2014) reported that 32 teachers in a special needs school Pekanbaru did not receive their salary in 3 months, they also reported that the salary is not well balanced with the work that they did. The fact that special needs education teachers are not being well supported by organization can affect their affective commitment (Rhoades \& Eisenberger, 2002) which later impact on their performance (Rhoades \&Eisenberger, 2002; Mercurio, 2015; Mayer \& Allen, 2007).

In this case, being a special needs education teacher requires great patience and attentive when teaching children with special needs, because the students character are very sensitive and hard to maintain (Rosdiana, 2013). 
Thus, it is very important to have affective commitment as a teacher because affective commitment associated with the widest range of behavioral variables such as helping others, working extra hours, information sharing, and supervisor's evaluation of performance (Solinger et al., 2008) as it will also impact the quality of education.

Affective attachment and employees effort outcome expectancies can be strengthen with perceived organizational support which also resulting in greater effort to fulfill the organization's goals (Eisenberger et al, 1986).Employees who are emotionally committed to the organization display heightened performance, reduced absenteeism, and a lessened likelihood of quitting their job (Mathieu \& Zajac, 1990; Meyer \& Allen, 1997; Mowday, Porter, \& Steers, 1982, in Rhoades \& Eisenberger, 2002). Positive work experience also provides employees perceptions of organizational support which reflects perceptions of an organizations commitment to its employees (Shore \& Wayne, 1993). Studies have found that employees with high positive organizational support suffer less stress at work (Shaw et al, 2013) and positively relates to performance (Rhoades \& Eisenberger, 2002). Thus, organization can best serve their employees by developing policies and strategies to contribute to positive employee beliefs and attitudes about the organization (Eisenberger, Malone, \& Presson, 2016).

As for Indonesia which is one of developing countries that starting to build educational system for children with disability, it is important to learn about how to increase the quality in special needs education system. Recognizing that the special needs educational teachers demand more attention, this research attempts to present insight about perceived organizational support among shadow teachers in public school.

\section{THEORETICAL FRAMEWORK}

Perceived organizational support defined as "how much the organization values employees" contributions and cares about them (Allen et al., 2008, in Colakoglu et al., 2010), also supposes to determine the organization's readiness to reward increased work effort and to meet socio-emotional needs, employees develop global beliefs concerning the extent to which the organization values their contributions and cares about their well-being (Eisenberger, Huntington, Hutchison, \& Sowa, 1986). Perceived organizational support (POS) is also valued as assurance that aid will be available from the organization when it is needed to carry out one's job effectively and to deal with stressful situations (George, Reed, Ballard, Colin, \& Fielding, 1993, in Eisenberger \& Rhoades, 2002).

There are three general forms of perceived favorable treatment received from the organization, such as fairness, supervisor support, and organizational rewards and job conditions which should increase POS (Eisenberger et al., 1986, in Eisenberger \& Rhoades, 2002).

\section{RESEARCH METHOD}

The author, firstly, conduct a literature review about the current state of the research. Secondly, several special needs educational teachers who had worked at public school with special needs students were interviewed as primary data for the study.

This research using the concept of perceived organizational support with three beneficial factors for POS: fairness, organizational rewards and job conditions. In qualitative research, purposive sampling strategies are often applied (Miles and Huberman, 1994). Such 
strategies designed to enhance understanding of the specific phenomenon by selecting information rich cases that provide the greatest insight into the research questions.

\section{RESULT AND DISCUSSION}

Special needs educational teachers were felt less supported by the organization (educational department Surabaya). In this case, the subjects are well aware that the reward and the job-demand not always balance but still hoping that they can receive a better reward and condition at the public school with inclusive system. Not only reward and job conditions, some teachers did not feel supported by the fairness in how the regulation works which affect their commitment (Eisenberger et al., 1986).
The reward and job-condition predictors: recognition, pay, and promotions; job security; role stressors; training; and organization size (Eisenberger \& Rhoades, 2002). None of the teachers (3 subjects) felt appreciated by their organization in terms of recognition and role stressors. Teachers' extra work was rarely recognized, although they already gave their time and energy to work overtime for the special needs children. Also, in many public schools that accommodate children with disabilities are still lack of facilities and manpower. This, later create stress among special needs educational teacher, because they have to meet the curriculum target with limited facility and, possibly, overwork them-selves.

The second factor that needs to be improved is supervisor support. Supervisors act as

Table 1 Interview Conclusion from the Three Subjects (Special Need Educational Teachers in Public School)

\begin{tabular}{|c|c|}
\hline Aspects & Interview Conclusion \\
\hline Fairness & $\begin{array}{l}\text { The organization (DIKMEN) needs to improve their regulation in terms of } \\
\text { accepting new special children. Because there are many children with } \\
\text { disability who won't well-developed if they are educated at public school. } \\
\text { Not only because they need a lot more care which the school cannot } \\
\text { provide, the children with severe disability will need a lot more attention } \\
\text { which the shadow teachers cannot give fully. Shadow teachers also feel less } \\
\text { supported by the organization because DIKMEN wasn't always including } \\
\text { shadow teachers input in the decision process when accepting new special } \\
\text { need children. Shadow teachers also feel less supported by the organization } \\
\text { because DIKMEN wasn't always including shadow teachers input in the } \\
\text { decision process when accepting new special need children. This already } \\
\text { created confusion among shadow teachers in schools and they felt } \\
\text { burdened by the current regulation about accepting new special need } \\
\text { children }(\mathrm{V}, \mathrm{D}, \mathrm{W}) \text {. }\end{array}$ \\
\hline $\begin{array}{l}\text { Supervisor } \\
\text { support }\end{array}$ & $\begin{array}{l}\text { In terms of supervisor support, the shadow teachers or GPK (Guru Pen- } \\
\text { damping Khusus) have different valuation from each other. But, the } \\
\text { similarity is about lack of direction and feedback from supervisor about } \\
\text { their teaching process. So far, this matter didn't any problem although } \\
\text { sometimes it can lead to confusion about the job-description (V,D,W). }\end{array}$ \\
\hline $\begin{array}{l}\text { Rewards and job } \\
\text { condition }\end{array}$ & $\begin{array}{l}\text { In this case, teachers are well aware that the reward and the job-demand } \\
\text { not always balance but still hoping that they can receive a better reward } \\
\text { and condition at the public school with inclusive system. The job condi- } \\
\text { tions which lead them to feel not well supported are recognition and role } \\
\text { stressors. }(\mathrm{V}, \mathrm{D}, \mathrm{W}) \text {. }\end{array}$ \\
\hline
\end{tabular}


agents of the organization, having responsibility for directing and evaluating subordinates' performance, employees view their supervisor's favorable or unfavorable orientation toward them as indicative of the organization's support (Eisenberger et al., 1986; Levinson, 1965, in Eisenberger \& Rhoades, 2002). In this case, the teachers rarely get clear instruction and positive feedback. Most of the time, special needs education teachers initiate their own way to educate or teach the special needs children in each classes and grades. Other cases, the organization often dismissed any complaints from special need educational teachers which made them feel less supported.

The organization (DIKMEN) needs to improve their regulation in terms of accepting new special children, because there is still a lot of miscommunication between the organization and teachers. The special need educational teachers feel less supported because the organization wasn't always including the teachers input in the decision process when accepting new special need children. This already created confusion among shadow teachers in schools and they felt burdened by the current regulation about accepting new special need children.

Special needs educational teacher need a lot of support from the organization, not only because teaching children with disability need extra patient but also as a human being they need appreciation. Teachers can feel supported when the organization applying fairness, supportive supervisor, and a good reward and jobcondition (Rhoades \& Eisenberger, 2002). It is necessary for the educational department as an organization to improve the perceived organizational support among special need educational teachers, especially in terms of supervisor support, reward and job-condition This can lead to a better performance (Eisenberger et al., 1986) which later impact on the quality of special need education system in public school.

\section{IMPLICATIONS}

Research indicates that shadow teachers' post organizational support still need improvement in terms of regulation, reward and job conditions, and supervisor support. The implications from this research based on the result is reasons to change some regulations and giving more support to the shadow teachers in schools to improve their performance and well being. Further, the educational department view post organizational support as important to the shadow teachers in schools which later improve their performance. The educational department should maintain their support towards shadow teachers who are committed to students and to teaching as a career.

\section{REFERENCES}

Colakoglu, U., Culha, O., \& Atay, H.A. 2010. The Effects of Perceived Organizational Support on Employees' - Affective Outcome: Evidence from the Hotel Industry. Tourism and Hospitality Management, 16, 125-150.

Efendi, Mohammad. 2018. The Implementation of Inclusive Education in Indonesia for Children with Special Needs. Expectation and Reality. Journal of ICSAR, 2, 10-11.

Eisenberger, R., Huntingon, R., Hutchison, S., \& Sowa, D. 1986. Perceived Organizational Support. Journal of Applied Psychology, 71, 500-507.

Eisenberger, R., Malone, G.P., \& Presson, W.D. 2016. Optimizing Perceived Organizational 
Support to Enhance Employee Engagement. Society for Human Resource Management and Society for Industrial and Organizational Psychology, 2, 22.

Firmansyah, I. \& Widuri, E.L. 2014. Subjective Well-Being pada Guru Sekolah Luar Biasa (SLB). Empathy, 2(1), 1-8.

Mercurio, Z.A. 2015. Affective Commitment as a Core Essence of Organizational Commitment: An Integrative Literature Review. Human Resource Development Review. Vol. 14(4), 389-414.

Rhoades, L. \& Eisenberger, R. 2002. Perceived Organizational Support: A Review of the
Literature. Journal of Applied Psychology. 87(4), 698-714.

Solinger, O.N., van Olffen, W., \& Roe, R.A. 2008. Beyond the Three-Component Model of Organizational Commitment. Journal of Applied Psychology, 93(1), 7083.

Sugianto. 2012. "Guru Mojokerto Minta Diperhatikan". Koran Pendidikan.

Zakia, D.L. 2015. Guru Pembimbing Khusus (GPK): Pilar Pendidikan Inklusi. Prosiding Ilmu Pendidikan, 1(2). 